\title{
Effects of Climate Change on Mountain Waters: A Case Study of European Alps
}

\author{
Abdul Nasir Laghari \\ Department of Energy and Environment \\ Engineering, Quaid-e-Awam University \\ of Engineering, Science and Technology, \\ Nawabshah, Pakistan \\ a.n.laghari@quest.edu.pk
}

\author{
Gordhan Das Walasai \\ Department of Mechanical Engineering, \\ Quaid-e-Awam University of \\ Engineering, Science and Technology, \\ Nawabshah, Pakistan \\ valasai@quest.edu.pk
}

\author{
Abdul Rehman Jatoi \\ Department of Energy and Environment \\ Engineering, Quaid-e-Awam University \\ of Engineering, Science and Technology, \\ Nawabshah, Pakistan \\ jatoi.ar@gmail.com
}

\author{
Daddan Khan Bangwar \\ Department of Civil Engineering, Quaid -e- Awam University \\ of Engineering, Science and Technology, Nawabshah, Pakistan \\ skb_khan2000@yahoo.com
}

\author{
Abdul Hannan Shaikh \\ Department of Mathematics. Quaid e Awam University of \\ Engineering, Science, and Technology, Nawabshah, Pakistan \\ hanangul12@yahoo.co.uk
}

\begin{abstract}
The Alps play a vital role in the water supply of the region through the rivers Danube, Rhine, $P$ o and Rhone while they are crucial to the ecosystem. Over the past two centuries, we witnessed the temperature to increase by +2 degrees, which is approximately three times higher than the global average. Under this study, the Alps are analyzed using regional climatic models for possible projections in order to understand the climatic changes impact on the water cycle, particularly on runoff. The scenario is based on assumptions of future greenhouse gases emissions. The regional model results show the consistent warming trend in the last 30-year span: temperature in winter may increase by 3 to $4.5^{\circ} \mathrm{C}$ and summers by 4 to $5.5^{\circ} \mathrm{C}$. The precipitation regime may also be altered: increasing about 10$50 \%$ in winter and decreasing about $30-60 \%$ in summer. The changes in the amount of precipitation are not uninformed. Differences are observed particularly between the North West and South East part of the Alps. Due to the projected changes in alpine rainfall and temperature patterns, the seasonality of alpine flow regime will also be altered: massive rise will occur in winter and a significant reduction in summer. The typical low flow period during winter will also be shifted to late summer and autumn.
\end{abstract}

Keywords-climate change; European Alps; flow regime; impact assessment

\section{INTRODUCTION}

The Alps, spanning over the central part of Europe, play a key role in the water supply of the region. The chain of this mountain region known as the "water towers" of Europe are a mother to number of rivers, i.e., Danube, Rhine, Po, and Rhone. These rivers provide key services to the ecosystem both at upstream and the downstream regions. Worryingly, mountain regions and the Alps in particular are highly exposed to the climate change. The region has witnessed a remarkably rise in temperature of approximately $+2^{\circ} \mathrm{C}$ during the last two hundred years against the global mean surface temperature increase of $0.74^{\circ} \mathrm{C}$ [1]. The Alps are highly sensitive to climate change, even a slight variation in climatic parameters can significantly change the hydrological cycle. Seasonal snow and ice factor have strong altitude sensitivity concerning temperature conditions, so the variation in temperature could result in sharp changes both to the Alpine climate and hydrology [2]. The increased temperature rate has severely affected the alpine hydro-climate system, i.e., extensive glacier retreat, decline in snow cover duration, rise of snowline, variations in seasonal runoff regime etc. [3].

Authors in [4-6] analyzed the precipitation in the region and reported a rise in rainfall in winter season by $20-30 \%$ and a reduction in autumn by $20-40 \%$. The buildup of snow at higher elevations may form glaciers, and during summer, when precipitation and runoff are low, their melting provides water to low-lying areas. The rivers Rhine, Rhone, and Inn, show stable and higher mean specific discharges of $28-331 / \mathrm{s}$ per $\mathrm{km}^{2}$ in comparison with Po, Adige and Mur which show lower and variable mean specific discharges of $17-241 / \mathrm{s}$ per $\mathrm{km}^{2}$. However, due to the three times higher impact of global warming, any further temperature change shall result in change in the Alps hydrological cycle. The two-third of this water volume were lost by 2000 and $10 \%$ of the volume was lost just in the hot summer of 2003 [7]. If this trend continues, the large glaciers will lose about $30-70 \%$ of their remaining volume by $2050[8,9]$.

It is projected that the changes in the hydro-climate system will be further intensified in the coming decades, resulting into increased number of summer droughts, winter floods and higher inter-mean annual variation in river runoff regimes [1012]. Anticipated shortfall of water along with continual intense events and with the growth in water demand will have negative impact on the ecosystem. Agriculture, energy use, forestry, winter-tourism, and river transportation are highly susceptible to water shortage. These changes in temperature have left 
drastic impacts on the alpine ecosystem, e.g., the hydrological cycle of Alps. This could be noticed in: a rise in mean rainfall amounts and extreme precipitation events [2, 10-12], a retreat in alpine glaciers [13-15], decline in snow cover [16, 17], and increased flood events $[18,19]$. The extent and frequency of these impacts will further be worsened over the coming decades [20, 22]. Carrying out future projections of how the temperature and precipitation change will impact the water cycle depends heavily upon the future world evolution in terms on energy use and emissions. The IPCC uses four different SRES scenarios. These scenarios are likely imageries of evolution under a variety of assumptions and are tools which can used to analyze the role of driving forces and their impacts on the future greenhouse gases emissions. In this study emission scenario A2 is used due to socio-economic development, demographic changes and hi-tech change, which are the primary precursors behind the development of this emission scenario family. Therefore, the prediction of the future water cycle is based on the assumption of emission scenario A2 and their impact on temperature, precipitation patterns, and flow volume generated in Alpine region.

\section{STUDY AREA DESCRIPTION}

The Alpine region is a curvy shaped geographic facet of central Europe. It forms an arc of approximately $800 \mathrm{~km}$ and is $200 \mathrm{~km}$ in width. The mean altitude of alpine peaks is $2.5 \mathrm{~km}$. The arc is elongated above the Po basin from the north Mediterranean Sea, stretching through France towards Switzerland. The arc prolongs towards Austria, and east to Slovenia [23-25]. It descends into northern Italy in South and extends to the southern border of Germany in North [23]. The most of the alpine territory is covered by Switzerland, Austria, Italy and France. The region serves as a huge natural water storage site its reserves benefit many rivers throughout the region, i.e. Rhine, Danube, Po and Rhone, whose headwaters originate from the alpine region. Figure 1 shows the major river basins originating in the Alps. The region possesses paramount importance due to its abundant water resources.

The increased precipitation rate and reduced evaporation loss due to its low temperature is the main reason for surplus water availability in region. The greater part of the precipitation is snowfall at high elevations. The accumulation of snow at high altitudes may form a glacier- a prominent feature of alpine mountain hydrology. These glaciers occupy about $2900 \mathrm{~km}^{2}$ of the total area of the Alpine region. During summer season, when precipitation and runoff are low, the glacier melt provides important services to low-laying areas [26]. The Alp's average yearly share varies from $25 \%-53 \%$ of the total flow for Danube and Po respectively. The mountain part of Danube basin (around $10 \%$ of total basin area) provides $25 \%$ of total flow, producing 2.6 of disproportional influence. Similarly, the mountain parts of the Rhine, Rhone, and Po basin account for $34 \%, 41 \%$, and $53 \%$ of their total discharge, implying a disproportional influence of $2.3,1.8$, and 1.5 for each basin respectively [27]. The contribution from the Alpine part varies between seasons. The major contribution comes in summer. In the Po basin, the mountain part provides below $40 \%$ of total flow in winter and more than $80 \%$ in summer months.

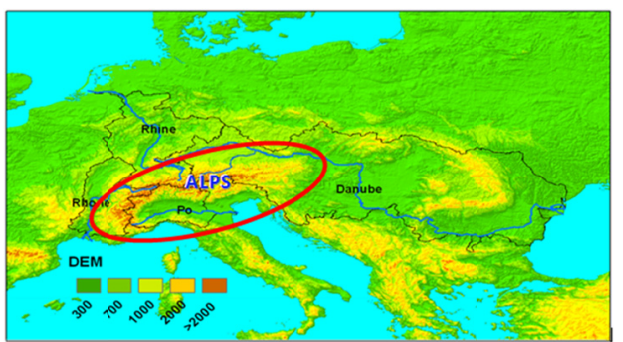

Fig. 1. Major rivers originating in the European Alps: Rhine, Rhone, Po and Danube

\section{FUTURE PROJECTIONS}

The regional climate model (CLM) shows consistent warming trends during the last 30 years of the $21^{\text {st }}$ century: the mean alpine temperature in winters may rise by 3 to $4.5^{\circ} \mathrm{C}$ and in summers by 4 to $5.5^{\circ} \mathrm{C}$ depending on the greenhouse-gas emission scenario A2 [28]. The precipitation is anticipated to be higher in cold season and lower in warm season. Figure 2 shows the future projections of relative seasonal change in temperature by the end of the $21^{\text {st }}$ century. These climatic projections were simulated through the CLM under the strong IPCC emissions scenario A2.

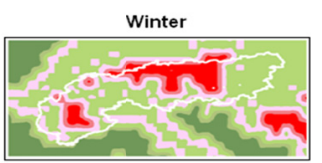

Summer

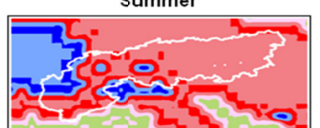

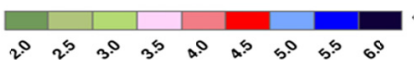

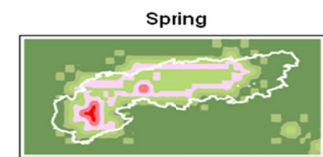

Autumn

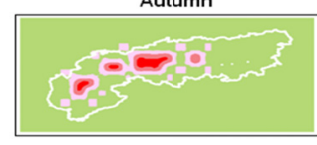

Fig. 2. Absolute seasonal changes ((2070-2099) / (1961-1990)) in mean temperature till the last 30 -year span of the $21^{\text {st }}$ century, as per regional CLM A2 scenario. Rasters are developed from the data available at Prudence project website, http://prudence.dmi.dk/.

The A2 scenario represents a typical range of probable future directions. The CLM model simulations for the 20712100 period show an average rise in yearly temperature of about $4-5^{\circ} \mathrm{C}$ in the Alps while annual precipitation rate is slightly changed. However, the precipitation rate is strongly varied from season to season. The precipitation rate in winter will be increased to about $10-50 \%$ and in summer decreased to about $30-60 \%$. The increased temperature scenario has a drastic effect on seasonal snowfall and melting processes. The sensitivity of alpine snow cover towards projected temperature increase is a recurring research topic. Analysis in [29] indicated that the projected increase of about $4^{\circ} \mathrm{C}$ until the last two decades of the current century will have a significant effect over the middle to low altitude catchments. The analysis projected that the current snow volume in the Alps might completely vanish to altitudes up to $1000 \mathrm{~m}$. The snow duration is also expected to be reduced at large extent. These findings were also confirmed in $[30,31]$. By their conclusion, for each degree of rise in the temperature, the snow-cover is likely to decrease by few weeks at mid altitudes. Particularly below 
$700 \mathrm{~m}$, the snow depletion may reach $33 \%$ with an average of 30 days reduction in the winter season. The average snow line is projected to decrease around $150 \mathrm{~m}$ with each degree of temperature increase [32]. The projected increased temperatures have a very negative impact on glacier cover. Authors in [9] suggest that at a rise in temperature of about 4$5^{\circ} \mathrm{C}$, the glacier cover will be reduced more than $80 \%$. This means the small glaciers will be disappeared by 2050 and sizable glaciers will face a $30-70 \%$ volume reduction. The increased glacier melt will initially enhance the summer flows in the alpine rivers, but later on, when the glacier volume will be reduced, summer flows are projected to be reduced [33]. The flows of highly glacierized basins may face up to $50 \%$ reduction in summer season [32]. In the long term, the projected reduced summer precipitation amount and little contribution from glacier melt may all result in much-reduced summer flows [34-36], and may even result in increased droughty conditions at downstream regions. On the other hand, the projected increased precipitation rates together with early and faster snowmelt may also create a higher risk of flooding during the winter season. The projected tempo-spatial alteration in the hydrological cycle of Alps can be seen in Figure 3.

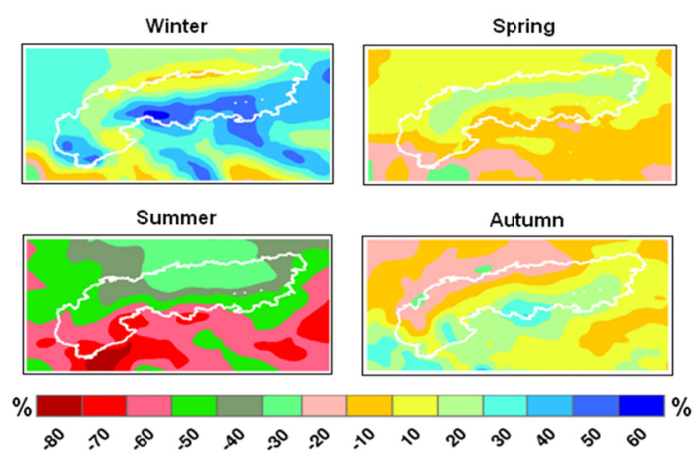

Fig. 3. Relative seasonal changes ((2070-2099) / (1961-1990)) in mean precipitation amount till the last 30 -year span of $21^{\text {st }}$ century, as per CLM A2 scenario Geo-Rasters are developed from the data available at Prudence project website, http://prudence.dmi.dk/.

Figure 4 shows the impact of climate change over the hydrological regime of the Alps (e.g. tempo-spatial changes in seasonal runoffs), simulated through the regional climate model (CLM) under IPCC emissions scenario A2. The high temperature in winter not only results in changing precipitation form (from solid to liquid) but also causes early snowmelt during winter (instead of spring). Figure 4 shows that the climate change will undoubtedly induce drastic effect over seasonality of alpine river flow regime. The variation in seasonal runoffs ranges from $70 \%$ to $80 \%$ increase in winter to $40-50 \%$ decrease in summer. Runoff regime analysis confirms the similar trends in seasonality of alpine rivers, e.g. the Rhine or the Rhone. Similar conclusion were also drawn earlier in [16], which highlights the substantial shift in water availability in different seasons throughout the year, with a potential risk of enhancing flooding in late winter and enhanced drought in late summer and early autumn. These decreasing trends in all seasons (except in winter) may affect the different demand stakeholders within the Alps, but the major problem may be created in adjacent lowland regions.
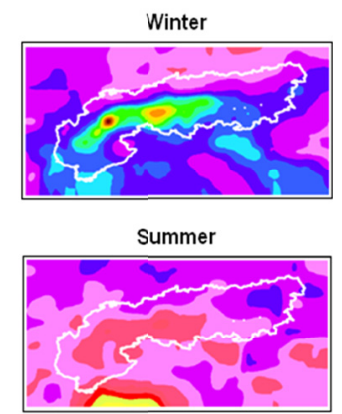

$\%$

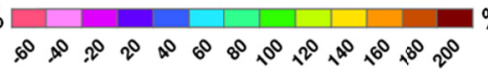

Fig. 4. Relative seasonal changes ((2070-2099) / (1961-1990)) in mean runoff till the last 30 -year span of $21^{\text {st }}$ century, as per regional CLM A2 scenario. Rasters are developed from the data available at Prudence project website, http://prudence.dmi.dk/ through the application of Arc GIS software.

\section{CONCLUSION}

The Alps are sensitive to climatic changes and are already experiencing higher increases in temperature than the European and global average. The CLM model results show the same trend of changes during the last decades of the $21^{\text {st }}$ century: higher increase in winter and summer temperature. The futuristic precipitation patterns give mixed signals: rise in winter and fall in summer. This would clearly point out that the snow-cover span shall be reduced to fewer weeks, the snowline is projected to shift upwards, the smaller glaciers will be vanished, and the sizable glaciers shall suffer huge volume reduction by the last decades of this century. The seasonality of flow regime will be highly affected having a rise in winter and a significant fall in summer months.

\section{REFERENCES}

[1] IPCC, The Fourth Assessment Report of the Intergovernmental Panel on Climate Change, IPCC, 2007

[2] A. Laghari, D. Vanham, W. Rauch, "To what extent does climate change result in a shift in Alpine hydrology? A case study in the Austrian Alps", Hydrological Sciences Journal, Vol. 57, No. 1, pp. 103-117, 2012

[3] I. Auer, R. Bohm, A. Jurkovic, W. Lipa, A. Orlik, R. Potzmann, W. Schoner, M. Ungersbock, C. Matulla, K. Briffa, P. Jones, D. Efthymiadis, M. Brunetti, T. Nanni, M. Maugeri, L. Mercalli, O. Mestre, J. - M. Moisselin, M. Begert, G. Muller - Westermeier, V. Kveton, O. Bochnicek, P. Stastny, M. Lapin, S. Szalai, T. Szentimrey, T. Cegnar, M. Dolinar, M. Gajic - Capka, K. Zaninovic, Z. Majstorovic, E. Nieplova, "HISTALP - Historical instrumental climatological surface time series of the Greater Alpine Region 1760-2003", International Journal of Climatology, Vol. 27, No. 1, pp. 17-46, 2007

[4] I. Auer, R. Bohm, A. Jurkovic, A. Orlik, R. Potzmann, W. Schoner, M. Ungersbock, M. Brunetti, T. Nanni, M. Maugeri, K. Briffa, P. Jones, D. Efthymiadis, O. Mestre, J. - M. Moisselin, M. Begert, R. Brazdil, O. Bochnicek, T. Cegnar, M. Gajic - Capka, K. Zaninovic, Z. Majstorovic, S. Szalai, T. Szentimrey, L. Mercalli, "A new instrumental precipitation dataset for the greater alpine region for the period 1800-2002", International Journal of Climatology, Vol. 25, No. 2, pp. 139-166, 2005

[5] C. Schar, C. Frei, "Orographic precipitation and climate change", in: Global Change and Mountain Regions, pp. 255-266, Springer, 2005

[6] J. Schmidli, C. Schmutz, C. Frei, H. Wanner, C. Schar, "Mesoscale precipitation variability in the region of the European Alps during the 
20th century", International Journal of Climatology,Vol. 22, No. 9, pp. 1049-1074, 2002

[7] W. Haeberli, Spuren des Hitzesommers 2003 im Eis der Alpen. Submission to the parliament of Switzerland, 2003 (in German)

[8] L. K. Bogataj, "Effects of Climate Change to the Alps - Water Towers to Europe", in: Adaptation of Water Management to Effects of Climate Change in the Danube River Basin, Conference Proceedings, Austrian Ministry for European and International Affairs, 2007

[9] F. Paul, A. Kaab, M. Maisch, T. Kellenberger, W. Haeberli, "Rapid disintegration of Alpine glaciers observed with satellite data", Geophysical Research Letters, Vol. 31, No. 21, 2004

[10] C. D. Schonwiese, J. Rapp, Climate trend atlas of Europe based on observations 1891-1990, Springer, 1997

[11] D. Gellens, "Trend and correlation analysis of k-day extreme precipitation over Belgium", Theoretical and Applied Climatology, Vol. 66, No. 1-2, pp. 117-129, 2000

[12] C. Frei, C. Schar, "Detection probability of trends in rare events: theory and application to heavy precipitation in the Alpine region", Journal of Climate, Vol. 14, No. 7, pp. 1568-1584, 2001

[13] R. Frauenfelder, M. Laustela, A. Kaab, "Relative age dating of Alpine rockglacier surfaces", Zeitschrift fur Geomorphologie, Vol. 49, No. 2, pp. 145-166, 2005

[14] 14. M. Huss, S. Sugiyama, A. Bauder, M. Funk "Retreat scenarios of Unteraargletscher, Switzerland, using a combined ice-flow mass-balance model", Arctic, Antarctic, and Alpine Research, Vol. 39, No. 3, pp. $422-$ 431, 2007

[15] W. Haeberli, M. Hoelzle, F. Paul, M. Zemp, "Integrated monitoring of mountain glaciers as key indicators of global climate change: the European Alps", Annals of Glaciology, Vol. 46, pp. 150-160, 2007

[16] M. Beniston, "Mountain Climates and Climatic Change: An Overview of Processes Focusing on the European Alps", Pure Applied Geophysics, Vol. 162, No. 8-9, pp. 1587-1606, 2005

[17] D. Vanham, W. Rauch, "Climate Change and its Influence on Mountain Snow Covers: Implication for Drinking Water in the European Alps", International Journal of Climate Change: Impacts and Responses, Vol. 1, No. 4, pp. 101-112, 2009

[18] P. Y. Groisman, R. W. Knight, T. R. Karl, "Heavy precipitation and high streamflow in the contiguous United States: trends in the twentieth century", Bulletin of the American Meteorological Society, Vol. 82, No. 2, pp. 219-246, 2001

[19] P. C. D. Milly, R. T. Wetherald, K. A. Dunne, T. L. Delworth, "Increasing risk of great floods in a changing climate", Nature, Vol. 415, pp. 514-517, 2002

[20] G. A. Meehl, T. Karl, D. R. Easterling, S. Changnon, R. Pielke Jr., D. Changnon, J. Evans, P. Ya. Groisman, T. R. Knutson, K. E. Kunkel, L. O. Mearns, C. Parmesan, R. Pulwarty, T. Root, R. T. Sylves, P. Whetton, F. Zwiers, "An introduction to trends in extreme weather and climate events: Observations, socioeconomic impacts, terrestrial ecological impacts, and model projections", Bulletin of the American Meteorological Society, Vol. 81, pp. 413-416, 2000

[21] P. D. Jones, P. A. Reid, "Assessing future changes in extreme precipitation over Britain using regional climate model integrations", International Journal of Climatology, Vol. 21, pp. 1337-1356, 2001

[22] T. N. Palmer, J. Raisanen, "Quantifying the risk of extreme seasonal precipitation events in a changing climate", Nature, Vol. 415, pp. 512514,2002

[23] K. M. Fleming, J. A. Dowdeswell, J. Oerlemans, "Modelling the mass balance of northwest Spitsbergen glaciers and responses to climate change", Annals of Glaciology, Vol. 24, pp. 203-210, 1997

[24] A. Beattie, The Alps: A cultural history, Oxford University Press, 2006

[25] B. Chatre, G. Lanzinger, M. Macaluso, W. Mayrhofer, M. Morandini, M. Onida, B. Polajnar, "The Alps: People and Pressures in the Mountains, the Facts at a Glance", in: Permanent Secretariat of the Alpine Convention: Vademecum, Innsbruck, Austria, 2010

[26] H. P. Liniger, R. Weingartner, R. Grosjean, M. Agenda, Mountains of the World: Water Towers for the 21st Century, Mountain Agenda c/o Institute of geography University of Berne, 1998.
[27] R. Weingartner, D. Viviroli, B. Schadler, "Water resources in mountain regions: a methodological approach to assess the water balance in a highland-lowland-system”, Hydrological Processes, Vol. 21, pp. 578585,2007

[28] ClimChAlp, Final report on Climate Change, Impacts and Adaptation Strategies in the Alpine Space, 2008

[29] M. Beniston, F. Keller, B. Koffi, S. Goyette, "Estimates of snow accumulation and volume in the Swiss Alps under changing climatic conditions", Theoretical and Applied Climatology, Vol. 76, No. 3-4, pp. $125-140,2003$

[30] E. Martin, P. Etchevers, "Impact of climatic change on snow cover and snow hydrology in the French Alps", in: Global Change and Mountain Regions (A State of Knowledge Overview), pp. 235-242, Springer, 2005

[31] M. Hantel, L. M. Hirtl-Wielke, "Sensitivity of Alpine snow cover to European temperature", International Journal of Climatology, Vol. 27, No. 10, pp. 1265-1275, 2007

[32] B. Zierl, H. Bugmann, "Global change impacts on hydrological processes in Alpine catchments", Water Resources Research, Vol. 41, No. 2, 2005

[33] R. Hock, P. Jansson, L. Braun, "Modelling the response of mountain glacier discharge to climate warming", in: Global Change and Mountain Regions, pp. 243-252, Springer, 2005

[34] J. Andreasson, G. Lindstrom, G. Grahn, B. Johansson, "Runoff in Sweden - Mapping of Climate Change Impacts on Hydrology", in: XXIII Nordic Hydrological Conference, Tallinn, Estonia, August, 2004

[35] K. Jasper, P. Calanca, D. Gyalistras, J. Fuhrer, "Differential impacts of climate change on the hydrology of two alpine river basins", Climate Research, Vol. 26, No. 2, pp. 113-129, 2004

[36] T. P. Barnett, J. C. Adam, D. P. Lettenmaier, "Potential impacts of a warming climate on water availability in snow-dominated regions", Nature, Vol. 438, No. 7066, pp. 303-309, 2005 